\title{
Tilaruokinnalla kilpailukykyä siipikarjatuotantoon
}

\author{
Timo Karhula \\ MTT Taloustutkimus, Latokartanonkaari 9, 00790 Helsinki \\ timo.karhula@mtt.fi
}

\section{TIIVISTELMÄ}

Tilaruokinnalla, eli sekoittamalla rehu tilalla eri raaka-aineista, voidaan siipikarjatiloilla saada tuotantokustannussäästöjä täysrehuruokintaan nähden. Tutkimustulosten mukaan broilerituotannossa vuotuiset säästöt ovat laskelmissa käytetyillä hinnoilla ja oletuksilla keskimäärin noin 0,4 €/broileria ja kananmunantuotannossa noin $2 € /$ kanaa kohden. Säästöjen toteutumiseksi tuotantoon on kuitenkin panostettava ja siinä on onnistuttava. Joissain ruokintakokeisiin perustuvissa laskelmissa broilerituotannon osalta oli päästävä korkeisiin teuraspainoihin osin lyhyemmässä kasvatusajassa ja kananmunantuotannon laskelmissa munatuotoksen oli pysyttävä korkeana, jotta tilaruokinta olisi taloudellisesti varteenotettava vaihtoehto. Tilaruokinnassa voidaan käytännössä kyllä onnistua, sillä hankkeen yhteistyötilojen tuotanto- ja taloustulokset ovat hyvin lupaavia. Tuotantokustannussäästöt olivat tiloilla huomattavasti keskimääräistä suurempia. Tiloilla on panostettu erityisen paljon tuotantoon ja ammattitaitoon ja se näkyy positiivisesti sekä tuotantotuloksissa että tilojen taloudessa.

Tilaruokinnan aloittaminen edellyttää investointeja sekä rehusekoittamoon että rehujen varastotiloihin. Jos rehujen hintamuutokset onnistutaan tiloilla hyödyntämään, maksavat investoinnit tätä kautta itsensä takaisin suhteellisen nopeasti. Lisäksi, jos tilaruokinnalla saadaan hyviä tuloksia, tulevat investoinnit katettua vielä nopeammin. Ongelmana ovat kuitenkin rehujen nopeat ja suuretkin hintavaihtelut, johon ruokinnassa ei välttämättä kyetä samanaikaisesti vastaamaan.

Hintamuutokset muuttavat siipikarjatilan taloudellisen tilanteen herkästi. Rehukustannusten osuus tuotantokustannuksesta on tiloilla jopa $40-50 \%$, joten ruokinnassa onnistuminen tai epäonnistuminen näkyy suoraan koko tilan kannattavuudessa. Tämä merkitsee sitä, että rehuihin, ruokintaan ja sen suunnitteluun kannattaa tiloilla panostaa. Usein säästökohteita nähdään vain muuttuvissa kustannuksissa, kuten rehuissa, mutta säästämällä vääristä kohdista voidaan kannattavan tuotannon edellytykset samalla menettää.

Asiasanat: tilaruokinta, broileri, kana, kannattavuus, tuotantokustannus 


\section{Johdanto}

Suomen siipikarjasektori on ollut viime vuosina kovassa nousukiidossa. Siipikarjanlihan tuotanto on lisääntynyt 2000 -luvun alusta lähes 70 \% ja kananmunien tuotantomäärät ovat yhtä korkealla kuin viimeksi 1990 -luvulla. Myös siipikarjatilojen yhteenlasketut markkinahintaiset kokonaistuotot ovat kautta aikojen korkeimmalla tasollaan. Kokonaistuotot ovat vuonna 2013 arvion mukaan yhteensä noin 235 milj. euroa, josta broilerituotot muodostavat noin 157 milj. euroa ja kananmunatuotot noin 78 milj. euroa. Kokonaistuottojen kasvua viime vuosina selittävät sekä munien että broilerinlihan lisääntynyt tarjonta ja vahvistuneet tuottajahinnat.

Siipikarjatilojen kannattavuudessa on kuitenkin parantamisen varaa, vaikka niiden taloudellisen tilanteen arvioidaan olevan maataloussektorin tuotantosuunnista parhaimmalla tasolla. Vuodelle 2012 kannattavuuskertoimeksi muodostui 0,76 ja vuodelle 2013 kannattavuuskertoimen arvioidaan olevan 0,56, kun tavoitteena kertoimella on yksi (Taloustohtori 2013). Tämä merkitsee sitä, että ennalta asetetusta viljelijäperheen palkkavaatimuksesta ja oman pääoman korkovaatimuksesta joudutaan vuodesta riippuen tinkimään noin neljännes tai puolet pois. Kannattavuuden parantaminen voidaan siten nähdä siipikarjatilojen ykköstavoitteena.

Tiukan taloudellisen tilanteen aikana huomiota kannattaa kiinnittää myös eläinten ruokintaan ja ruokintamenetelmiin. Yksi vaihtoehto ruokintaan on tilaruokintaan siirtyminen. Tilaruokinnalla tarkoitetaan eläinten rehun sekoittamista tilalla eri raaka-aineista eli komponenteista. Tilaruokinnan laitteisiin tehdyt investoinnit voivat parantaa mahdollisuuksia käyttää esimerkiksi tilan omia tai lähialueen tiloilta saatavia rehun raaka-aineita, kuten eri viljoja tai valkuaiskasveja. Tilaruokinnalla tavoitellaan tuotantokustannussäästöjä ja yritetään näin osaltaan parantaa siipikarjatalouden kannattavuutta.

\section{Aineisto ja menetelmä}

Tässä tutkimuksessa selvitettiin erilaisten tilaruokintavaihtoehtojen vaikutuksia siipikarjatilojen talouteen laatimalla tilamallilaskelmia sekä broileri- että kananmunantuotannosta. Laskelmiin otettiin mukaan broileri- ja kananmunantuotanto niiden taloudellisen merkittävyyden vuoksi sektorilla. Mallilaskelmilla selvitettiin tavanomaisen (täysrehuruokinnan) ja tilaruokinnan välistä kannattavuus- ja tuotantokustannuseroa. Molemmista tuotantosuunnista tehtiin kahdeksan rinnakkaista laskelmaa eri ruokintavaihtoehtojen pohjalta.

Mallilaskelmien lisäksi tutkimuksessa oli mukana tilaruokintaa käyttäviä yhteistyötiloja. Yhteistyötiloista toinen oli kananmunatila ja toinen broileritila. Tiloilta saatujen tietojen perusteella laskettiin taloudelliset tulokset molemmille tiloille. Muut laaditut laskelmat perustuvat MTT:n aineistoihin, siipikarjaa koskeviin ruokintasuunnitelmiin ja ruokintakokeisiin sekä niiden tuloksiin.

\section{Tulokset}

Tutkimustulosten mukaan siipikarjantuotannossa saadaan tuotantokustannussäästöjä laskelmissa käytetyillä hinnoilla ja oletuksilla. Broilerituotannossa vuotuiset säästöt ovat parhaassa tapauksessa keskimäärin noin 0,4 €/broileria ja kananmunantuotannossa noin $2 € /$ kanaa kohden. Säästöjen toteutumiseksi tuotantoon on kuitenkin panostettava ja siinä on onnistuttava hyvin. Joissain ruokintakokeisiin perustuvissa laskelmissa broilerituotannon osalta oli päästävä korkeisiin teuraspainoihin osin lyhyemmässä kasvatusajassa ja kananmunantuotannon laskelmissa munatuotoksen oli pysyttävä korkeana, jotta tilaruokinta olisi taloudellisesti varteenotettava vaihtoehto. 


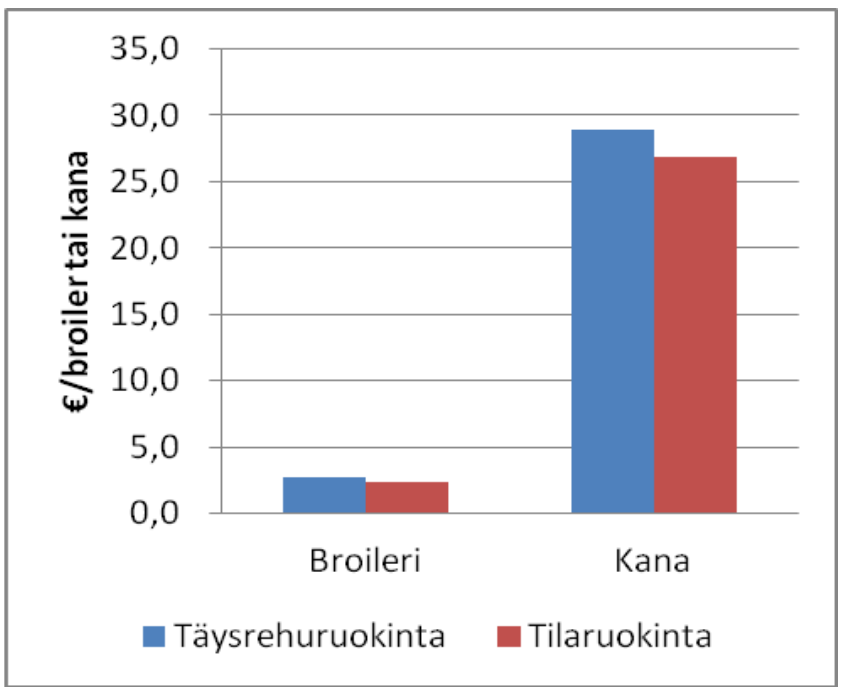

Kuva 1. Broileri- ja kananmunantuotannon keskimääräinen tuotantokustannus täysrehuruokinnalla ja tilaruokinnalla (€/broiler tai kana).

Tilaruokinnassa voidaan myös käytännössä onnistua, sillä hankkeen yhteistyötilojen tuotanto- ja taloustulokset ovat hyvin lupaavia. Yhteistyötiloista broileritilalla on saavutettu hyviä tuotantotuloksia tilaruokinnalla, mikä on johtanut tuotannon hyvään kannattavuuteen. Tilalla on saavutettu korkeita teuraspainoja hyvällä rehuhyötysuhteella normaalissa kasvatusajassa. Rehuissa ja niiden laadussa tilalla ei ole kuitenkaan tingitty, vaan päinvastoin, niihin on kiinnitetty erityistä huomiota.

Myös kananmunia tuottavalla yhteistyötilalla tehdään tilaruokinnan avulla hyvää tulosta. Tähän ovat edesauttaneet oma rehusekoitus, ruokinnan optimointi, tiivis ja tarkka tuotannon, eläinten ja olosuhteiden seuranta sekä nopeat korjaustoimenpiteet mahdollisten epäkohtien korjaamiseksi. Hyviä tuotantotuloksia on edesauttanut minimaalinen lattiamunien osuus. Rehunkulutus on tilalla pysynyt hyvin kurissa, sillä hyvällä rehuhyötysuhteella on päästy hyviin tuotantotuloksiin.

Myös taloustulokset puhuvat tilasekoituksen puolesta molemmilla yhteistyötiloilla. Tuotantokustannukset ovat alhaisemmat ja tuotot korkeammat kuin täysrehuruokintaan perustuvassa ruokinnassa. Tilojen kannattavuus onkin hyvällä tasolla, joten niillä jää viljelijäperheen työlle ja omalle pääomalle parempi korvaus kuin muilla tiloilla.

Tilaruokinnan aloittaminen edellyttää investointeja sekä rehusekoittamoon että rehujen varastotiloihin. Jos rehujen hintamuutokset onnistutaan tiloilla hyödyntämään, maksavat investoinnit tätä kautta itsensä takaisin suhteellisen nopeasti. Lisäksi, jos tilaruokinnalla saadaan hyviä tuloksia, tulevat investoinnit katettua vielä nopeammin. Ongelmana ovat kuitenkin rehujen nopeat ja suuretkin hintavaihtelut, johon ruokinnassa ei välttämättä kyetä samanaikaisesti vastaamaan.

\section{Johtopäätökset}

Siipikarjatiloilla rehukustannusten osuus tuotantokustannuksesta on jopa $50 \%$, joten ruokinnassa onnistuminen tai epäonnistuminen näkyy suoraan koko tilan kannattavuudessa. Tämä merkitsee sitä, että rehuihin, ruokintaan ja sen suunnitteluun kannattaa tiloilla panostaa. Usein säästökohteita nähdään vain muuttuvissa kustannuksissa, kuten rehuissa, mutta säästämällä vääristä kohdista voidaan kannattavan tuotannon edellytykset samalla menettää.

Onnistuneella tilasekoituksella voidaan parantaa siipikarjatilojen kannattavuutta, sillä tulosten mukaan tuotantokustannussäästöt ja myös lisätuotot ovat mahdollisia tilaruokinnassa. Tuotannossa on kuitenkin tällöin onnistuttava ja siihen on panostettava. Hintamuutokset muuttavat siipikarjatilan taloudellisen tilanteen kuitenkin herkästi, suuntaan tai toiseen.

Tilaruokinta on mahdollisuus siipikarjatiloille, sillä yhteistyötilojen tuotanto- ja taloustulokset ovat hyvin lupaavia. Tiloilla on panostettu rehuihin, tuotantoon ja ammattitaitoon erityisen paljon ja se näkyy positiivisesti sekä tuotannossa että taloudessa. Rehuissa ei ole tiloilla tingitty, mutta osin ongelmallisena nähtiin laadukkaiden tilasekoitukseen soveltuvien rehukomponenttien saanti. 
SUOMEN MAATALOUSTIETEELLISEN SEURAN TIEDOTE NRO 30

\section{Kirjallisuus}

Taloustohtori 2013. Saatavissa: https://portal.mtt.fi/portal/page/portal/taloustohtori/kannattavuuskirjanpito/ aikasarja/Kannattavuuskerroin_tuotantosuunnittain. Viitattu 2.12.2013. 